\title{
Fibrinolytic bacteria of Indonesian fermented soybean: preliminary study on enzyme activity and protein profile
}

\author{
Fathma SYAHBANU ${ }^{a}$ (D), Elisabeth KEZIA ${ }^{b}$, Narwastu PUERA ${ }^{b}$, Puspo Edi GIRIWONO ${ }^{a}$, \\ Raymond Ruby TJANDRAWINATAc ${ }^{c}$, Maggy Thenawidjaja SUHARTONO ${ }^{\text {a* }}$
}

\begin{abstract}
A number of fibrinolytic enzyme producing microorganisms have been identified in various fermented food in Asia, such as from Red Oncom, Tempe, Terasi (Indonesia), Natto (Japan), Douchi, Soy paste (China), Meju, Kimchi, Jeot-gal, Tofuyo, Chungkook-jang, Soybean paste and Doen-jang (Korea). The high protein content in soybean is potential to promote the growth of proteolytic and fibrinolytic producing microbes. This study investigated several fibrinolytic bacteria, isolated from the moromi stage of the fermented soysauce production. The fibrinolytic activities of the isolates were confirmed in a fibrin plate assay, and all 3 potential isolates (K1, K2, and K3) were identified as Gram positive, rod shaped, and spore forming bacteria. Moreover, analysis of the sequences encoding 16S rRNA gene, revealed K1 as Bacillus cereus, K2 as Bacillus subtilis, and K3 as Bacillus cereus. SDS PAGE analysis demonstrated different protein profile of the cell free supernatant of isolates grown in LB media during fermentation, which ranged from 18.40-45 kDa.
\end{abstract}

Keywords: fermented soybean; fibrinolytic protease; moromi.

Practical Application: Finding of fibrinolytic activity of bacteria isolated from moromi stage in the fermented soysauce production accentuate the importance development of the enzyme into a powerful health product to treat thrombus related disease.

\section{Introduction}

Annually, cardiovascular diseases (CVDs), including stroke and heart diseases have been identified as the leading cause of death worldwide. Meanwhile, WHO data estimated about 17.9 million related deaths in 2016 , which represents $31 \%$ of all global cases, and about $85 \%$ occurred due to heart attack and stroke. In addition, out of the 17 million premature demise, i.e., under the age of 70 , the proportion attributed to noncommunicable diseases as reported in 2015 were $82 \%$ of low- and middle income countries, and $37 \%$ were caused by CVDs (World Health Organization, 2017). Moreover, the basic pathophysiology of stroke involves formation and attachment of fibrin clot or thrombus to the injured blood vessel walls.

Fibrin is the major protein component of blood clots, formed from fibrinogen by thrombin (Voet \& Voet, 1997), and the fibrinolytic enzymes are thrombolytic agents that are capable of dissolving fibrin clots. In addition, the agents that act as fibrinolytics, including urokinase plasminogen activator (u-PA), tissue plasminogen activator (t-PA), and streptokinase, have been adopted in the treatment of CVDs, while thrombolytic agents, encompassing t-PA and u-PA are classified as generally safe, although very expensive, with the propensity to cause undesirable side effects, including gastrointestinal bleeding (Peng et al., 2003; Killer et al., 2010; Jeong et al., 2015; Yogesh
\& Halami, 2017). In recent decades, many related studies on enzymes obtained from food-grade microorganisms have been proven as safe thrombolytic agents (Joo et al., 2002; Mine et al., 2005; Simkhada et al., 2010; Afifah et al., 2014; Stephani et al., 2017; Kurnia et al., 2017).

Therefore, the bacterial strains of Bacillus subtilis A26 (Agrebi et al., 2009), Bacillus amyloliquefaciens (Wei et al., 2011), Paenibacillus sp. IND8 (Vijayaraghavan \& Prakash Vincent 2014), Xenorhabdus indica KB-3 (Pranaw et al., 2014), and Bacillus sp. (Anh et al., 2015) were recently adopted in the production of fibrinolytic enzymes. In addition, a research on such enzymes from food microbes has been conducted in Japan, using Tofuyo (Fujita et al., 1993), Skipjack (Sumi et al., 1995), and Natto (Fujita et al., 1993; Chang et al., 2000; Seo \& Lee, 2004), Korea (Chungkook-jang (Kim et al., 1996 a, b), Jeot-gal (Hyun-Kuk Kim et al., 1997), Kimchi (Noh et al., 1999), Doen-jang (Kim \& Choi, 2000; Choi et al., 2005), Soybean paste (Lee et al., 2001), and Meju (Jo et al., 2011), China (Douchi (Peng \& Zhang, 2002) and Chinese soy paste (Wei et al., 2011), and Indonesia (Terasi and Jambal roti, fermented fish (Prihanto et al., 2013), Red Oncom and Gembus Tempeh (Afifah et al., 2014). Considering the rich fermented local products present in Indonesia, similar research is still highly limited. 
Fermented soysauce is one of the food products from soybean, obtained through two steps in the manufacturing process, encompassing (1) solid-state (koji fermentation) where the output is dried and (2) salt fermentation, where the dry mass is mixed with brine solution to form a mash, termed "moromi", which is further fermented within various periods of aging (range from six months to one year) (Lee et al., 2013; Zhu \& Tramper, 2013). The high protein contents in the soybean is potential of being utilized as a media for growing proteolytic and fibrinolytic microorganism, and this preliminary study confirmed a strong activity from bacteria isolated at the moromi stage.

\section{Materials and methods}

In this study, the moromi of fermented soy sauce was obtained from PT. Logan Food Lombok Gandaria (Karanganyar, Central Java, Indonesia), while the bacteriological agar was purchased from Sigma, US and Luria Bertani media was procured from Scharlau, Spain. Fibrinogen sourced from bovine plasma was purchased from Sigma, US, and the API 50CHB kit for bacterial identification was obtained from BioMérieux S.A, France.

\subsection{Isolation of proteolytic bacterial strain from Moromi (Afifah et al., 2014)}

The process of isolating proteolytic microbe was conducted using Skim Milk Agar media (SMA), with the composition of bacteriological agar and skim milk (1.5\%). In addition, a total of $1 \mathrm{~mL}$ of moromi was dissolved in $10 \mathrm{~mL}$ sterile aquadest, which was then strirred to a point of homogenity (moromi solution). Therefore, $0.1 \mathrm{~mL}$ was collected and spread onto the surface of SMA media, using a sterile hockey stick, which was subsequently incubated at $37^{\circ} \mathrm{C}$ for 48 hours, and then the clear zone observed indicated the existance of the protease producing microbes. Furthermore, the protease colonies were isolated and purified until a pure culture in the form of a mono colony was obtained, which was then grown in slant agar, and saved as a stock in glycerol $50 \%$ for further analysis.

\subsection{Enzyme production (Afifah et al., 2014)}

One ose of the selected microbe was grown in $12.5 \mathrm{~mL}$ sterile Luria-Bertani broth media (LB), in order to obtain the optical density (OD) of 0.8 at $\lambda_{620 \mathrm{~nm}}$. Therefore, a total of $10 \%(\mathrm{v} / \mathrm{v})$ fermentation broth recorded to have reached the required value was mixed with $25 \mathrm{~mL} \mathrm{LB}$, and further incubated for $1,2,3,4$, and 7 days at $37{ }^{\circ} \mathrm{C}$ in the shaking incubator (120 rpm) (PolyScience, US). Furthermore, the production media with fibrinolytic protease content was taken at the appropriate time and centrifuged at $6000 \mathrm{~g}$ for 30 minutes at $4{ }^{\circ} \mathrm{C}$, and then the cell free supernatant was collected as the enzyme source for subsequent analysis.

\subsection{Fibrin plate assay (Astrup \& Mullertz, 1952)}

The Fibrinolytic bacteria were screened using a modified fibrin plate method (Astrup \& Mullertz, 1952), where a total of $0.5 \%$ fibrinogen (Sigma F3879, US) solution in $50 \mathrm{mM}$ sodium phosphate buffer ( $\mathrm{pH} 8$ ) was mixed with $2 \%$ agarose solution along with $0.02 \mathrm{~mL}$ of thrombin (Sigma T4648, US) solution
(100 NIH units). These were then applied to a petri dish, and left for 1 hour at room temperature to form a fibrin clot layer. In addition, a sterile glass tube (diameter $6 \mathrm{~mm}$ ) was used to make hole in the fibrin plate, to which twenty $\mu \mathrm{L}$ of the enzyme was dropped and incubated at $37^{\circ} \mathrm{C}$ for 20 hours. Therefore, the positive control utilized the commercial fibrinolytic enzyme termed Lumbrokinase from Lumbricus rubellus (Disolf DLBS1033, Dexa Medica, Indonesia) $(40 \mathrm{mg} / \mathrm{mL})$, prepared in a $20 \mathrm{mM}$ phosphate buffer. Moreover, the activity of fibrinolytic enzyme was estimated by measuring the dimensions of the clear zone on the fibrin plate.

\subsection{SDS PAGE (Laemmli, 1970)}

SDS-PAGE was conducted with $10 \%$ of separating and $4 \%$ stacking gel. Also, the cell free supernatant was dilluted in a sample buffer $5 x$ (containing $60 \mathrm{mM}$ Tris- $\mathrm{HCl}$ (pH 6.8), 25\% glycerol, $2 \%$ SDS, and $0.1 \%$ bromophenol blue (BPB)), and the gel was run at $100 \mathrm{~V}, 100 \mathrm{~mA}$ for 1 hour, up to the point where $\mathrm{BPB}$ reached the bottom. Therefore, the protein bands were visualized by staining the gel with Coomassie Blue (CBBGR) for 20 minutes, which was sequentially soaked in a destaining solution, in order to attain discoloration, and the apparent molecular mass of the protein was calculated using Broad Molecular Weight standard protein markers (ThermoFisher Scientific, US).

\subsection{Protein determination (Bradford, 1976)}

The protein concentration was analysed using the reagents consisting of $100 \mathrm{mg}$ Coomassie Brilliant Blue (CBB) G-250 in $50 \mathrm{~mL}$ ethanol $95 \%$ and $100 \mathrm{~mL}$ phosphate acid $85 \%$ in 1L. Therefore, Bovine Serum Albumin (BSA) was used as the protein standard, and the experiments were conducted in triplicates for each measurement.

\subsection{Identification of microorganisms}

The identification of microorganisms followed 3 steps, which include (1) microbiology analysis i.e. Gram staining, spore staining, and morphological examination, using a microscope with $1000 \mathrm{X}$ magnification. (2) Biochemical tests with kit API 50CHB (BioMérieux S.A, France) for Bacillus spp., followed by identification using Apiweb $^{\mathrm{Tm}}$ software. (3) Molecular identification, where the selected microorganisms were grown in LB media, and identified at the species level. In addition, the DNA was extracted using a DNA mini kit Qiagen (Qiagen, US), with a reaction mixture $(10 \mu \mathrm{L})$ that contained $1 \mu \mathrm{L}$ DNA template $(50 \mathrm{ng} / \mu \mathrm{L}), 0.25 \mu \mathrm{L}$ forward primer 63F (5'-CAG GCC TAA CAC ATG CAA GTC-3'), $0.25 \mu \mathrm{L}$ reverse primer 1387R (5'-GGG CGG AGT GTA CAA GGC-3'), $5 \mu \mathrm{L}$ PCR Master Mix (Qiagen, US), and $3.5 \mu \mathrm{L}$ Nuclease Free Water (Qiagen, US). Therefore, the amplification of 16S rRNA gene using a 2720 thermal cycler (Applied Biosystems, US) was performed as follows: pra-denaturation $\left(94^{\circ} \mathrm{C}, 5 \mathrm{~min}, 30\right.$ cycles $)$, denaturation $\left(94^{\circ} \mathrm{C}, 30 \mathrm{~min}, 30 \mathrm{cycles}\right)$, annealing $\left(50^{\circ} \mathrm{C}, 1 \mathrm{~min}\right.$, 30 cycles), extension $\left(72^{\circ} \mathrm{C}, 2 \mathrm{~min}, 30\right.$ cycles $)$, final extension $\left(72^{\circ} \mathrm{C}, 5 \mathrm{~min}\right)$, and cooling $\left(25^{\circ} \mathrm{C}, 10 \mathrm{~min}\right)$. Furthermore, the PCR products were purified using Accuprep purification kit (Bioneer, Korea), and sequenced using Sanger dideoxy sequencing (genetic analyzer 3730 Xl, Applied Biosystems, US) (Sanger \& Coulson, 
1975), and a sequence homogenity search was performed using BLAST in NCBI database (https://blast.ncbi.nlm.nih.gov/Blast. cgi). Moreover, pairwise and multiple sequence alignment were analyzed using Clustal X2 programs, while the Phylogenetic tree analysis required the use of Neighbor-Joining method (Saitou \& Nei, 1987).

\section{Results and discussion}

Microbes usually obtained in fermented food are Gram-positive bacteria, encompassing Bacillus sp., Lactobacillus sp., Staphylococcus sp., and Streptococcus hemolyticus, which tend to be easily screened from food and the environment. There are non-toxic and beneficial microorganisms for human health, including Bacillus pumilus JB-1 from Korean Cheonggukjang, which has long been known to produce immuno-stimulant substances. Research conducted by Wei et al., (2011) reported antioxidant activity in enzymes produced by B. amyloliquefaciens LSSE-62, obtained from fermented chickpea. Juan \& Chou (2010) and Lee et al. (2008) also reported similar activities in Bacillus subtilis and some fungi obtained from fermented legumes. Duc et al. (2004) stated the potential of Bacillus cereus, Bacillus clausii, and Bacillus pumilus to confer probiotic properties.

The 3 isolates (K1, K2, and K3) screened from moromi stage of soy sauce production were proven capable of producing fibrinolytic protease activity, as seen on the fibrin plate assay (Figure 1a). Specifically, K2 fermented at 1 day (K21) possessed the highest fibrinolytic activity of all, with the widest clear zone area of $1.50 \mathrm{~cm}$ in the fibrin plate. In addition, the measurement for $\mathrm{K} 1, \mathrm{~K} 2$, and $\mathrm{K} 3$ grown for 1 day (K11, K21, and $\mathrm{K} 31$ ) were between $1.30 \mathrm{~cm}$ and $1.50 \mathrm{~cm}$, which was higher than those fermented at 2 days (K12, K22, and K32), within the range of $0.81 \mathrm{~cm}$ and $1.08 \mathrm{~cm}$, and 3 days $(\mathrm{K} 13, \mathrm{~K} 23$, and $\mathrm{K} 33)$ of $0.65 \mathrm{~cm}$ to $1.23 \mathrm{~cm}$. Furthermore, the extracellular enzyme obtained from $\mathrm{K} 13$ possessed the lowest activity of about $0.65 \mathrm{~cm}$. In this case the protein concentrations of all samples evaluated were within the range $0.92-0.99 \mathrm{mg} / \mathrm{mL}$. The fibrinolytic activity of extracellular enzyme obtained from $\mathrm{K} 1, \mathrm{~K} 2$, and $\mathrm{K} 3$ isolates were compared with the commercial Lumbrokinase (LK), a fibrin degrading enzyme from earthworm Lumbricus rubellus, and Figure $1 \mathrm{~b}$ indicated a close similarity with the K21 enzyme.

Afifah et al. (2014) reported the production of fibrinolytic enzymes from bacteria isolated from Indonesian fermented Gembus tempe and Red oncom. Clear zone produced on the fibrin plate using similar method were $1.35 \mathrm{~cm}$ and $1.45 \mathrm{~cm}$, respectively. These values were less than that from the best isolate of the current study. Thus, the bacteria obtained from moromi stage of fermented soysauce, were proven capable of producing good fibrinolytic enzymes. Bacillus licheniformis, Bacillus cereus, Brevibacillus laterosporus, and Bacillus pumilus were the fibrinolytic bacteria identified from Red oncom and Gembus tempe (Afifah et al., 2014).

Based on Gram staining, spore staining, and morphological test, all of the isolates (K1, K2, and K3) were identified as rod-shaped Gram positive and spore producing bacteria (Figure $2 \mathrm{a}$ ). The results of biochemical tests using API $50 \mathrm{CHB}$ kit specifically for Bacillus spp, identified isolate K1 as Bacillus cereus 1 (99.8\%), K2 as Bacillus subtilis (97\%), and K3 as Bacillus cereus (99\%). Molecular identification based on $16 \mathrm{~S}$ rRNA's gene confirmed $\mathrm{K} 1$ as B. cereus 1 (100\%), K2 as B. subtilis (99.86\%), and $\mathrm{K} 3$ as $B$. cereus (97.56\%). The nucleotide sequences were deposited at GenBank, with accession number MK045762 for K1, MK652831 for K2, and MK530096 for K3, and the phylogenetic tree was constructed on the basis of the sequences as presented in Figure 2b.

The specific genus from fermented food that were reported earlier capable of producing strong fibrinolytic enzyme include Bacillus natto from Natto (Fujita et al., 1993), Bacillus

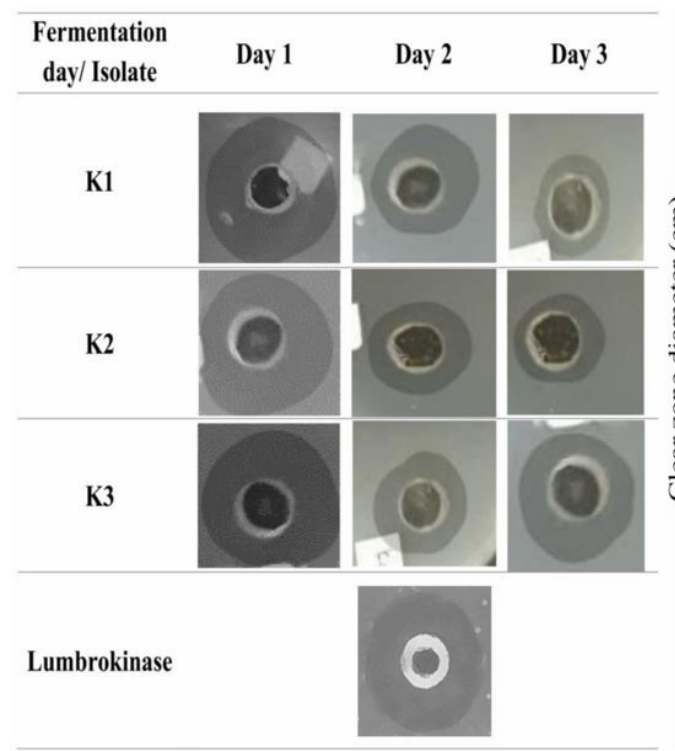

a

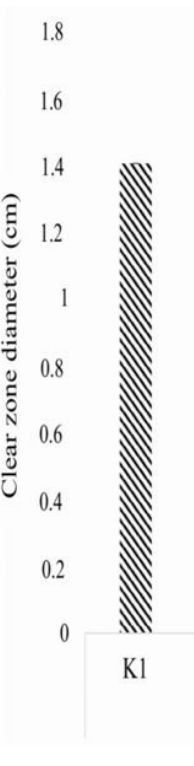

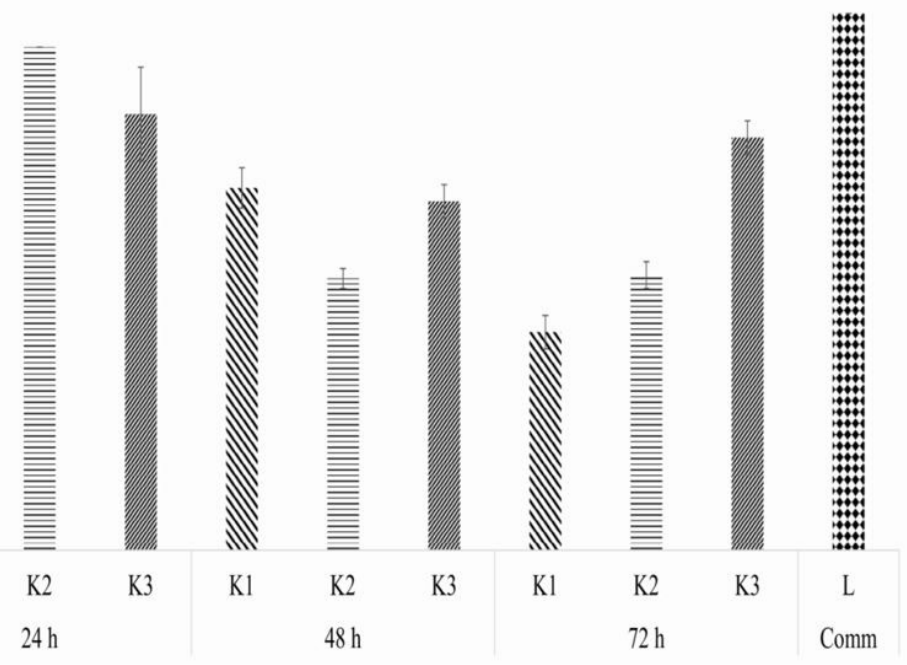

b

Figure 1. (a) Fibrinolytic activity shows in fibrin plate, (b) Fibrin degrading activity (cm) from fibrinolytic enzymes K1, K2, K3 grown at 24h, 48h, and 72h. L: Lumbrokinase. 

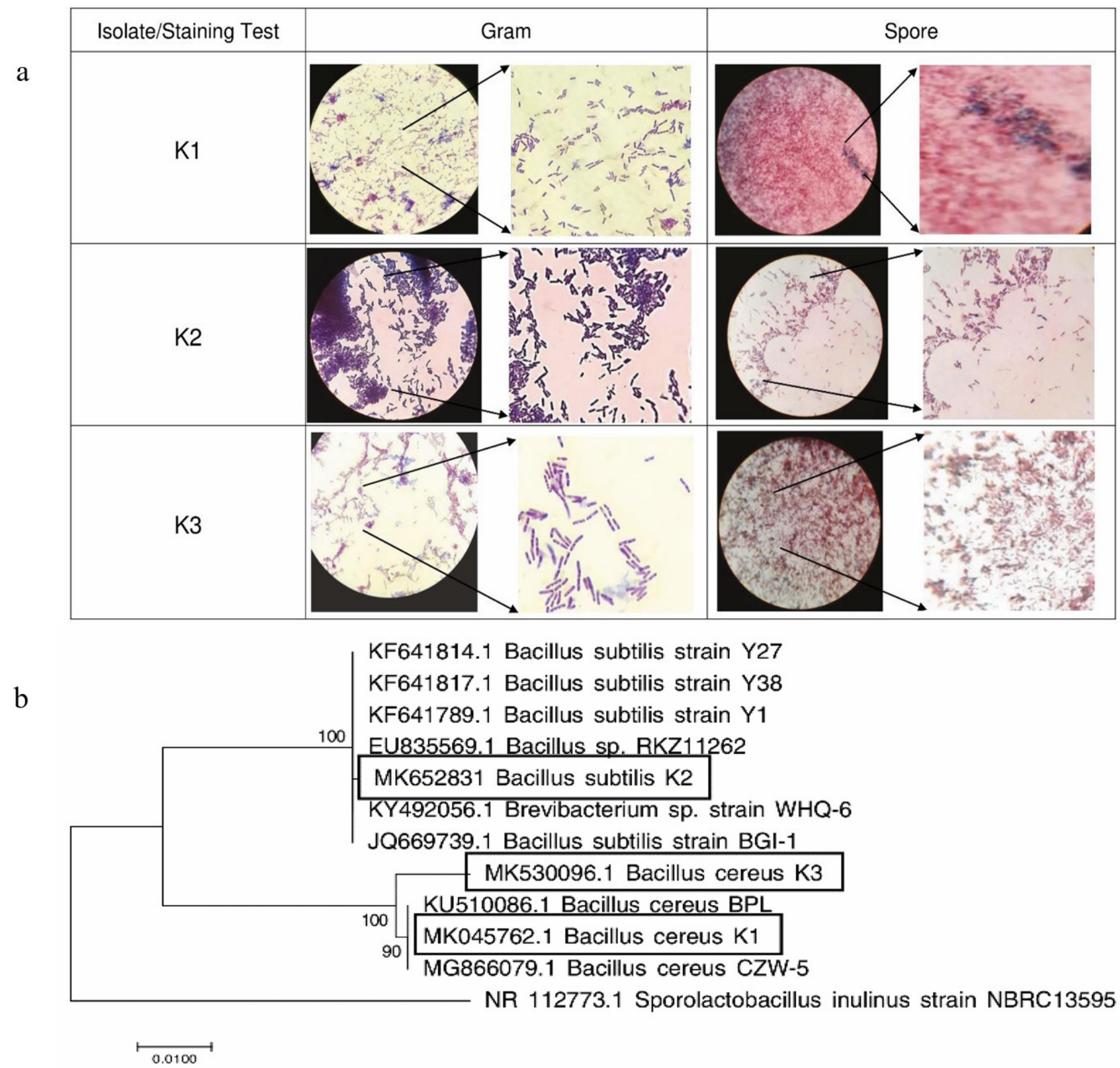

Figure 2. (a) Gram and spore staining of K1, K2, and K3 (magnification $1000 \mathrm{x}$ ); (b) Phylogenetic tree of the strains constructed based on sequence analysis of their $16 \mathrm{~S}$ rRNA gene.

amyloliquefaciens DC-4 from Douchi (Peng \& Zhang, 2002), Bacillus amyloliquefaciens MJ5-41 from Meju (Jo et al., 2011), Bacillus amyloliquefaciens LSSE-62 from Chinese soy paste (Wei et al., 2011), Bacillus sp. DJ-2 from Doen-jang (Choi et al., 2005), Bacillus licheniformis KJ-31 from Jeot-gal (Hwang et al., 2007), and Bacillus coagulans from Terasi, an Indonesian fermented fish (Prihanto et al., 2013).

Fermented foods are regarded as sources with potential fibrinolytic efficacy, as their active compounds are suspected to affect blood circulation Data on studies reporting fibrinolytic activity in various fermented foods are shown in Table 1.
The fibrinolytic activity of extracellular enzyme obtained from Bacillus cereus K1, Bacillus subtilis K2, and Bacillus cereus $\mathrm{K} 3$ isolate were comparable to the commercial product Lumbrokinase (LK) from earthworm (Lumbricus rubellus). This implies the useful potentials of the three new isolates (Bacillus subtilis and Bacillus cereus) in the production of fibrinolytic enzymes for health application, which in this case act as an anti thrombolytic agent.

Homeostasis is very important in the blood coagulation and fibrinolysis system because of the highly elaborated and complicated system, where both factors ought to be maintained at a balanced and well controlled state. In addition, the fibrin 
Table 1. Fermented food and fibrinolytic producing microorganism.

\begin{tabular}{|c|c|c|c|}
\hline Microorganism & Food & Enzyme & Reference \\
\hline Bacillus subtilis var natto & Vegetable cheese, Natto, Japan & Nattokinase & Sumi et al. (1987) \\
\hline Bacillus natto, NK & Natto, Japan & Nattokinase & Fujita et al. (1993) \\
\hline Bacillus sp. & Tofuyo, Japan & SMCE & Fujita et al. (1993) \\
\hline Katsuwonus pelamis & Skipjack, Japan & Katsuwokinase & Sumi et al. (1995) \\
\hline Bacillus sp. CK & Chungkook-jang, Korea & $\mathrm{CK}$ & Kim et al. (1996a,b) \\
\hline Bacillus sp. KA38 & Jeot-gal, Korea & Jeot-gal enzyme & Hyun-Kuk Kim et al. (1997) \\
\hline Bacillus sp. & Kimchi, Korea & Bacillus protease & Noh et al. (1999) \\
\hline Armillaria mella & Armillaria mella & Neutral metalloprotease & Kim \& Kim (1999) \\
\hline Bacillus sp. DJ-4 & Doen-jang, Korea & Subtilisin DJ-4 & Kim \& Choi (2000) \\
\hline Bacillus subtilis IMR-NK1 & Natto, Japan & Nattokinase & Chang et al. (2000) \\
\hline Bacillus sp. KDO-13 & Soybeanpaste, Korea & - & Lee et al. (2001) \\
\hline Enterococcus faecalis & Tempe, Indonesia & E. faecalis BRCA- 5 & Joo et al. (2002) \\
\hline Bacillus subtilis & Natto, Japan & Nattokinase & Yamashita et al. (2003) \\
\hline B. amyloliquefaciens DC-4 & Douchi, China & Subtilisin DFE & Peng et al. (2003) \\
\hline Bacillus subtilis QK02 & Fermented soybean & QK-1 and QK-2 & Ko et al. (2004) \\
\hline Bacillus firmus NA-1 & Natto, Japan & - & Seo \& Lee (2004) \\
\hline Bacillus sp. DJ-2 & Doen-jang, Korea & bpDJ-2 & Choi et al., (2005) \\
\hline Rhizopus chinensis 12 & Chinese wine, China & - & Xiao-lan et al. (2005) \\
\hline Fusarium sp & Tempe & - & Sugimoto et al. (2007) \\
\hline B. amyloliquefaciens & Fermented chickpeas, China & - & Wei et al. (2011) \\
\hline Bacillus coagulans & $\begin{array}{c}\text { Fermented fish, Jambal roti and } \\
\text { Terasi, Indonesia }\end{array}$ & - & Prihanto et al. (2013) \\
\hline Bacillus licheniformis $\mathrm{RO} 3$ & Red oncom, Indonesia & - & Afifah et al. (2014) \\
\hline Bacillus pumillus & Gembus, Indonesia & - & Afifah et al. (2014) \\
\hline Bacillus licheniformis & Soy flour & & Gad et al. (2014) \\
\hline Bacillus amyloliquefaciens & Spoilt milk & - & Gad et al. (2014) \\
\hline Bacillus subtilis ZA400 & Kimchi, Korea & BsfA & Ahn et al. (2015) \\
\hline Stenotrophomonas sp & Oncom, Indonesia & Stenoprotease & $\begin{array}{l}\text { Nailufar et al. (2016), } \\
\text { Kurnia et al. (2017) }\end{array}$ \\
\hline
\end{tabular}

converted from fibrinogen during thrombosis was identified as an insoluble protein, which is stabilized by thrombin-activated factor XIII through cross-linking (Furlan, 1988). Therefore, it is critical to decrease its redundant deposits at the sites of tissue injury, in order to fully restore potency to the damaged vessel. Furthermore, the fibrinolytic system, consisting of enzymes like plasmin, tissue plasminogen activator ( $t-P A)$, plasminogen activator inhibitors (PAIs), and urokinase are identified as the body's main defense mechanism against occlusive vascular diseases (Lijnen, 2001).

Thrombolytic agents have been identified in numerous organism, ranging from earthworm, snake, centerpede, mushroom, kelp, some algae and microrganisms (Kotb, 2012; Yogesh \& Halami, 2017). Hence, streptokinase from Streptococcus hemolyticus and staphylokinase from Staphylococcus aureus which act as plasminogen activator, have been adopted as thrombolytic agent's medicine to overcome thrombosis. Meanwhile, two other agents known to be effective (Kotb, 2012) include tissue-type plasminogen activator (t-PA) (Collen \& Lijnen, 2004) and urokinase (Duffy, 2002), which both activate plasminogen into active plasmin, in order to properly degrade fibrin. However, in addition to being expensive, certain side effects have been reported through injection application, which is possibly due to the presence of impurities or some imune active material in the preparation. This has, therefore, ignited the quest for a research on safer sources, including traditional fermented food.

The protein profile of extracellular enzymes produced from each isolate with different fermentation time were analysed with SDS PAGE (Figure 3), using about $0.92-0.99 \mathrm{mg} / \mathrm{mL}$ concentrations loaded into the gel. Generally, protein of $20 \mathrm{kDa}$ was present in almost all fermentation extract, and the elevation of fermentation time led to an increase in the protein synthesis performed by the bacterias. Therefore, the profiling illustrated the presence of only 1 or 2 protein bands on day 1 and 2, while higher protein varieties from 14 to $45 \mathrm{kDa}$, indicative of more protein bands, were found on the fermentation time of day 4 and 7 .

Table 2 shows the correlation between protein fractions observed in SDS PAGE profiling and proteolytic activity, pointing $20 \mathrm{kDa}$ protein as responsible for the fibrinolytic effects. In addition, the strongest activity was observed on day 1 of the fermentation extract in all isolates, followed by day 2 and 3, which imply that the fibrin degrading enzyme was synthesized at the early phase of growth.

Enzymes with fibrinolytic activities occur in diversed sizes: $18 \mathrm{kDa}$ from Bacillus polymaxa NRC-A (Mahmoud et al., 2011), 18.1 kDa as FCF-11 from Bacillus amyloliquefaciens FCF-11 (Kotb, 2014), $18.6 \mathrm{kDa}$ as thrombinase from Bacillus 


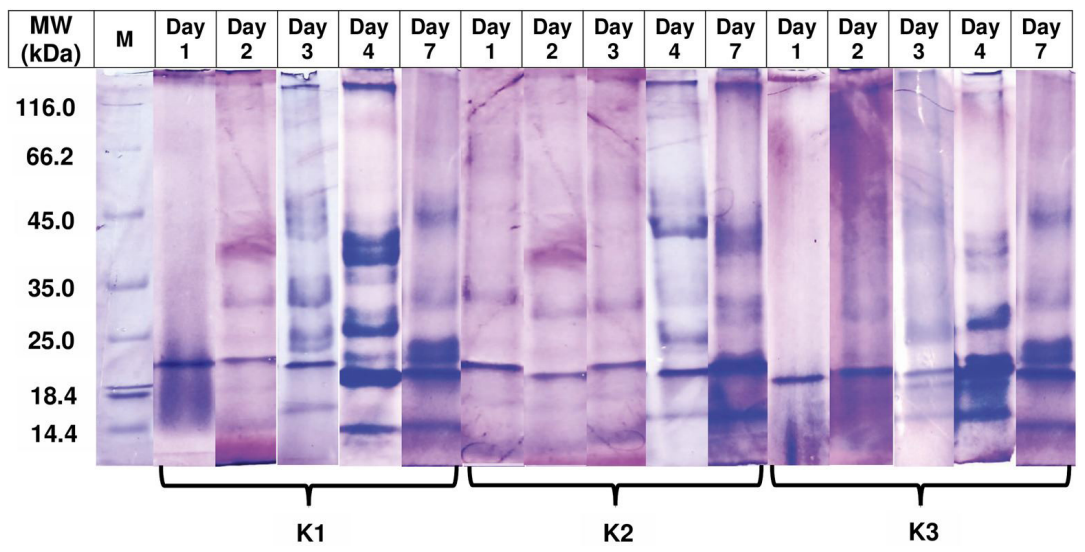

Figure 3. Protein profile in SDS PAGE.

Table 2. Protein fractions with various molecular weight observed during fermentation.

\begin{tabular}{|c|c|c|c|c|c|c|c|c|c|}
\hline \multirow{3}{*}{ Band (kDa) } & \multicolumn{9}{|c|}{ Isolate } \\
\hline & \multicolumn{3}{|c|}{ K1 } & \multicolumn{3}{|c|}{$\mathrm{K} 2$} & \multicolumn{3}{|c|}{ K3 } \\
\hline & $1 \mathrm{~d}^{\mathrm{a}}$ & $2 \mathrm{~d}$ & $3 d$ & $1 \mathrm{~d}$ & $2 \mathrm{~d}$ & $3 d$ & $1 d$ & $2 d$ & $3 d$ \\
\hline$<18$ & - & $\sqrt{ }$ & $\sqrt{ }$ & - & - & $\sqrt{ }$ & - & $\sqrt{ }$ & $\sqrt{ }$ \\
\hline $18-20$ & $\sqrt{ }$ & $\sqrt{ }$ & $\sqrt{ }$ & $\sqrt{ }$ & $\sqrt{ }$ & $\sqrt{ }$ & $\sqrt{ }$ & $\sqrt{ }$ & $\sqrt{ }$ \\
\hline $20-25$ & - & - & $\sqrt{ }$ & $\sqrt{ }$ & $\sqrt{ }$ & $\sqrt{ }$ & - & $\sqrt{ }$ & $\sqrt{ }$ \\
\hline $35-45$ & - & - & $\sqrt{ }$ & - & - & $\sqrt{ }$ & - & - & $\sqrt{ }$ \\
\hline $45-66$ & - & - & - & - & - & - & - & - & $\sqrt{ }$ \\
\hline$>66$ & - & - & $\sqrt{ }$ & - & - & $\sqrt{ }$ & - & - & - \\
\hline Fibrinolytic activity & +++ & ++ & + & +++ & + & + & +++ & ++ & ++ \\
\hline
\end{tabular}

note: ${ }^{\text {a }}$ shows fermentation time in day $(\mathrm{d}) ;+++$ very strong, ++ strong, + strong enough.

spharicus (Balaraman \& Prabakaran, 2007), $14 \mathrm{kDa}, 21 \mathrm{kDa}$, $35 \mathrm{kDa}$, and $46 \mathrm{kDa}$ as multiple proteases from Bacillus subtilis BR-21 (Yogesh \& Halami, 2015), and $45 \mathrm{kDa}$ from Bacillus sp. KDO-13 (Lee et al., 2001). Afifah et al. (2014) reported the extracellular enzymes with 20 to $41 \mathrm{kDa}$ produced from Bacillus isolated from Gembus tempe and Red oncom. Proteins with 20 to $41 \mathrm{kDa}$ obtained from the Bacillus cereus K1, Bacillus subtilis $\mathrm{K} 2$, and Bacillus cereus $\mathrm{K} 3$, possibly possess the strongest activity, especially the $21 \mathrm{kDa}$ and their purification is underway.

Fibrinolytic enzyme from bacteria are usually produced as several isozymes, including EfP-0-2 and EfP-II-2, which are the trypsin-like types present in glycosylated forms obtained from earthworm Eisenia fetida (Wu et al., 2007). F5 and F6 molecules are another trypsin-like serine protease isozyme isolated from Lumbricus rubellus (Cho et al., 2004). Whereas, F-III-2 and F-III-1 were the varieties obtained from Lumbricus rubellus (Nakajima et al., 1993). Ahn et al., 2015 reported the purified fibrinolytic BsfA enzyme from Bacillus subtilis ZA400 are $18.4-45 \mathrm{kDa}$ proteins, while the enzymes produced from Stenotrophomonas sp of Red oncom had molecules of 19 to $64 \mathrm{kDa}$ (Stephani et al., 2017).

\section{Conclusion}

Based on the results, it was established that Moromi from soysauce contains fibrinolytic bacteria, as confirmed by fibrin plate analysis. Moreover, based on morphological, biochemical and molecular evaluation, $\mathrm{K} 1, \mathrm{~K} 2$, and $\mathrm{K} 3$ isolates were confirmed as Gram positive, rod shaped, and spore forming Bacillus, where K1 was confirmed as Bacillus cereus, K2 Bacillus subtilis and K3 Bacillus cereus. All three isolates produced several proteins during fermentation process in the LB media.

\section{References}

Afifah, D.N., Sulchan, M., Syah, D., \& Suhartono, M. T. (2014). Isolation and identification of fibrinolytic protease-producing microorganisms from Red Oncom and Gembus, Indonesian fermented soybean cakes. Malaysian Journal of Microbiology, 10(4), 273-279. http:// dx.doi.org/10.21161/mjm.61914.

Agrebi, R., Haddar, A., Hmidet, N., Jellouli, K., Manni, L., \& Nasri, M. (2009). BSF1 fibrinolytic enzyme from a marine bacterium Bacillus subtilis A26: purification, biochemical and molecular characterization. Process Biochemistry, 44(11), 1252-1259. http://dx.doi.org/10.1016/j. procbio.2009.06.024.

Ahn, M. J., Ku, H. J., Lee, S. H., \& Lee, J. H. (2015). Characterization of a novel fibrinolytic enzyme, bsfa, from Bacillus subtilis ZA 400 in kimchi reveals its pertinence to thrombosis treatment. Journal of Microbiology and Biotechnology, 25(12), 2090-2099. http://dx.doi. org/10.4014/jmb.1509.09048. PMid:26403822.

Anh, D. B. Q., Mi, N. T. T., Huy, D. N. A., \& Van Hung, P. (2015). Isolation and optimization of growth condition of Bacillus sp. from fermented shrimp paste for high fibrinolytic enzyme production. Arabian Journal for Science and Engineering, 40(1), 23-28. http:// dx.doi.org/10.1007/s13369-014-1506-8.

Astrup, T., \& Mullertz, S. (1952). The fibrin plate method for estimating fibriolytic activity. Archives of Biochemistry and Biophysics, 40(2), 346351. http://dx.doi.org/10.1016/0003-9861(52)90121-5. PMid:12997222. 
Balaraman, K., \& Prabakaran, G. (2007). Production and purification of a fibrinolytic enzyme (thrombinase) from Bacillus sphaericus. The Indian Journal of Medical Research, 126(5), 459-464. PMid:18160751.

Bradford, M. M. (1976). A rapid and sensitive method for quantification of microgram quantities of protein utilizing the principles of protein dye binding. Analytical Biochemistry, 72(1-2), 234-254. http://dx.doi. org/10.1016/0003-2697(76)90527-3. PMid:942051.

Chang, C. T., Fan, M. H., Kuo, F. C., \& Sung, H. Y. (2000). Potent fibrinolytic enzyme from a mutant of Bacillus subtilis IMR-NK1. Journal of Agricultural and Food Chemistry, 48(8), 3210-3216. http:// dx.doi.org/10.1021/jf000020k. PMid:10956093.

Cho, I. H., Choi, E. S., Lim, H. G., \& Lee, H. H. (2004). Purification and characterization of six fibrinolytic serine-proteases from earthworm Lumbricus rubellus. Journal of Biochemistry and Molecular Biology, 37(2), 199-205. PMid:15469696.

Choi, N. S., Yoo, K. H., Hahm, J. H., Yoon, K. S., Chang, K. T., Hyun, B. H., Maeng, P. J., \& Kim, S. H. (2005). Purification and characterization of a new peptidase, bacillopeptidase DJ-2, having fibrinolytic activity: produced by Bacillus sp. DJ 2 from Doen-Jang. Journal of Microbiology and Biotechnology, 15(1), 72-79.

Collen, D., \& Lijnen, H. R. (2004). Tissue-type plasminogen activator: a historical perspective and personal account. Journal of Thrombosis and Haemostasis, 2(4), 541-546. http://dx.doi.org/10.1111/j.15387933.2004.00645.x. PMid:15102005.

Duc, L. H., Hong, A. H., Barbosa, T. M., Henriques, A. O., \& Cutting, S. M. (2004). Characterization of Bacillus probiotics available for human use. Applied and Environmental Microbiology, 70(4), 2161-2171. http://dx.doi.org/10.1128/AEM.70.4.2161-2171.2004. PMid:15066809.

Duffy, M. J. (2002). Urokinase plasminogen activator and its inhibitor, PAI-1, as prognostic markers in breast cancer: from pilot to level 1 evidence studies. Clinical Chemistry, 48(8), 1194-1197. http://dx.doi. org/10.1093/clinchem/48.8.1194. PMid:12142372.

Fujita, M., Nomura, K., Hong, K., Ito, Y., Asada, A., \& Nishimuro, S. (1993). Purification and characterization of a strong fibrinolytic enzyme (Nattokinase) in the vegetable cheese Natto, a popular soybean fermented food in Japan. Biochemical and Biophysical Research Communications, 197(3), 1340-1347. http://dx.doi.org/10.1006/ bbrc.1993.2624. PMid:8280151.

Furlan, M. (1988). Structure of fibrinogen and fibrin. In J. L. Francis (Ed.), Fibrinogen, fibrin stabilization, and fibrinolysis: clinical, biochemical and laboratory aspects (pp. 17-64). New York: Ellis Horwood, Ltd.

Gad, R. G., Nirmala, S., \& Sivvaswamy, S. N. (2014). Fibrinolytic enzyme from Bacillus amyloliquefaciens: optimisation and scale up studies. International Journal of Pharmacy and Pharmaceutical Sciences, 6(10), 370-378.

Hwang, K. J., Choi, K. H., Kim, M. J., Park, C. S., \& Cha, J. (2007). Purification and characterization of a new fibrinolytic enzyme of Bacillus licheniformis KJ-31, isolated from Korean traditional Jeotgal. Journal of Microbiology and Biotechnology, 9(9), 1469-1476. PMid:18062224.

Hyun-Kuk Kim, Gu-Taek Kim, Dae-Kyung Kim, Won-A Choi, SungHoon Park, Yong-Kee Jeong, \& In-Soo Kong. (1997). Purification and characterization of a novel fibrinolytic enzyme from Bacillus sp. KA38 originated from fermented fish. Journal of Fermentation and Bioengineering, 84(4), 307-312. http://dx.doi.org/10.1016/ S0922-338X(97)89249-5.

Jeong, S. J., Heo, K., Park, J. Y., Lee, K. W., Park, J. Y., Joo, S. H., \& Kim, J. H. (2015). Characterization of AprE176, a fibrinolytic enzyme from Bacillus subtilis HK176. Journal of Microbiology and Biotechnology, 25(1), 89-97. http://dx.doi.org/10.4014/jmb.1409.09087. PMid:25315053.
Jo, H. D., Lee, H. A., Jeong, S. J., \& Kim, J. H. (2011). Purification and characterization of a major fibrinolytic enzyme from Bacillus amyloliquefaciens MJ5-41 isolated from Meju. Journal of Microbiology and Biotechnology, 21(11), 1166-1173. http://dx.doi.org/10.4014/ jmb.1106.06008. PMid:22127128.

Joo, Y. S., Yu, M. E., Sim, G. S., Kwon, S. T., Hwang, J. K., Shin, J. K., Yeo, I. H., \& Pyung, Y. R. (2002). Screening and characterization of microorganisms with fibrinolytic activity from fermented foods. Journal of Microbiology and Biotechnology, 12, 649-656.

Juan, M. Y., \& Chou, C. C. (2010). Enhancement of antioxidant activity, total phenolic and flavonoid content of black soybeans by solid state fermentation with Bacillus subtilis BCRC 14715 . Food Microbiology, 27(5), 586-591. http://dx.doi.org/10.1016/j. fm.2009.11.002. PMid:20510775.

Killer, M., Ladurner, G., Kunz, A. B., \& Kraus, J. (2010). Current endovascular treatment of acute stroke and future aspects. Drug Discovery Today, 15(15-16), 640-647. http://dx.doi.org/10.1016/j. drudis.2010.04.007. PMid:20457274.

Kim, J. H., \& Kim, Y. S. (1999). A fibrinolytic metalloprotease from the fruiting bodies of an edible mushroom, Armillariella mellea. Bioscience, Biotechnology, and Biochemistry, 63(12), 2130-2136. http://dx.doi.org/10.1271/bbb.63.2130. PMid:10664846.

Kim, S. H., \& Choi, N. S. (2000). Purification and characterization of subtilisin DJ-4 secreted by Bacillus sp strain DJ-4 screened from Doen-Jang. Bioscience, Biotechnology, and Biochemistry, 64(8), 1722-1725. http://dx.doi.org/10.1271/bbb.64.1722. PMid:10993162.

Kim, W., Choi, K., Kim, Y., Park, H., Choi, J., Lee, Y., Oh, H., Kwon, I., \& Lee, S. (1996a). Purification and characterization of a fibrinolytic enzyme produced from Bacillus sp. strain CK 11-4 screened from Chungkook-Jang. Applied and Environmental Microbiology, 62(7), 2482-2488. http://dx.doi.org/10.1128/AEM.62.7.2482-2488.1996. PMid:8779587.

Kim, W., Choi, K., Kim, Y., Park, H., Choi, J., Lee, Y., Oh, H., Kwon, I., \& Lee, S. (1996b). Purification and characterization of a fibrinolytic enzyme produced from Bacillus sp. strain CK 11-4 screened from Chungkook-Jang. Applied and Environmental Microbiology, 62(7), 1488-2482. http://dx.doi.org/10.1128/AEM.62.7.2482-2488.1996. PMid:8779587.

Ko, J. H., Yan, J. P., Zhu, L., \& Qi, Y. P. (2004). Identification of two novel fibrinolytic enzymes from Bacillus subtilis QK02. Comparative Biochemistry and Physiology. Toxicology \& Pharmacology: CBP, 137(1), 65-74. http://dx.doi.org/10.1016/j.cca.2003.11.008. PMid:14984705.

Kotb, E. (2012). Fibrinolytic bacterial enzymes with thrombolytic activity. Berlin: Springer. http://dx.doi.org/10.1007/978-3-642-24980-8.

Kotb, E. (2014). Purification and partial characterization of a chymotrypsinlike serine fibrinolytic enzyme from Bacillus amyloliquefaciens FCF-11 using corn husk as a novel substrate. World Journal of Microbiology \& Biotechnology, 30(7), 2071-2080. http://dx.doi.org/10.1007/ s11274-014-1632-1. PMid:24609498.

Kurnia, F., Tjandrawinata, R. R., Yulandi, A., \& Suhartono, M. T. (2017). Protease of Stenotrophomonas sp. from Indonesian fermented food gene cloning and analysis. Journal of Biological Research (Thessaloniki), 90(2), 70-76.

Laemmli, U. K. (1970). Cleavage of structural proteins during the assembly of the head of bacteriophage T4. Nature, 227(5259), 680685. http://dx.doi.org/10.1038/227680a0. PMid:5432063.

Lee, I. H., Hung, Y. H., \& Chou, C. C. (2008). Solid-state fermentation with fungi to enhance the antioxidative activity, total phenolic and anthocyanin contents of black bean. International Journal of Food Microbiology, 121(2), 150-156. http://dx.doi.org/10.1016/j. ijfoodmicro.2007.09.008. PMid:18031859. 
Lee, J. S., Rho, S. J., Kim, Y. W., Lee, K. W., \& Lee, H. G. (2013). Evaluation of biological activities of the short-term fermented soybean extract. Food Science and Biotechnology, 22(4), 973-978. http://dx.doi. org/10.1007/s10068-013-0172-z.

Lee, S. K., Bae, D. H., Kwon, T. J., Lee, S. B., Lee, H. H., Park, J. H., Heo, S., \& Johnson, M. G. (2001). Purification and characterization of a fibrinolytic enzyme from Bacillus sp. KDO-13 isolated from soybean paste. Journal of Microbiology and Biotechnology, 11(5), 845-852.

Lijnen, H. R. (2001). Elements of the fibrinolytic system. Annals of the New York Academy of Sciences, 936(1), 226-236. http://dx.doi. org/10.1111/j.1749-6632.2001.tb03511.x. PMid:11460480.

Mahmoud, M. G., Ghazy, I. A., Ibrahim, S., Fahmy, A. S., El-Badry, M. O., \& Abdel-Aty, A. M. (2011). Purification and characterization of a new fibrinolytic enzyme of Bacillus polymaxa NRC-A. International Journal of Academic Research, 3, 542-547.

Mine, Y., Kwan Wong, A. H., \& Jiang, B. (2005). Fibrinolytic enzymes in Asian traditional fermented foods. Food Research International, 38(3), 243-250. http://dx.doi.org/10.1016/j.foodres.2004.04.008.

Nakajima, N., Mihara, H., \& Sumi, H. (1993). Characterization of potent fibrinolytic enzymes in earthworm Lumbricus rubellus. Bioscience, Biotechnology, and Biochemistry, 57(10), 1726-1730. http://dx.doi. org/10.1271/bbb.57.1726. PMid:7764268.

Nailufar, F., Tjandrawinata, R. R., \& Suhartono, M. T. (2016). Thrombus degradation by fibrinolytic enzyme of Stenotrophomonas sp. originated from Indonesian soybean-based fermented food on Wistar rats. Advances in Pharmacological Sciences, 1-9. http://dx.doi. org/10.1155/2016/4206908.

Noh, K. A., Kim, D. H., Choi, N. S., \& Kim, S. H. (1999). Isolation of fibrinolytic enzyme producing strains from kimchi. Korean Journal of Food Science Technology, 31, 219-223.

Peng, Y., \& Zhang, Y. Z. (2002). Optimation of fermentation conditions of douchi fibrinolytic enzyme produced by Bacillus amyloliquefaciens DC-4. Chinese Journal of Applied and Environmental Biology, 8, 285-289.

Peng, Y., Huang, Q., Zhang, R., \& Zhang, Y. (2003). Purification and characterization of a fibrinolytic enzyme produced by Bacillus emyloliquefaciens DC-4 screened from douchi, a traditional Chinese soybean food. Journal of Biochemistry and Molecular Biology, 134(1), 45-52. http://dx.doi.org/10.1016/S1096-4959(02)00183-5. PMid:12524032.

Pranaw, K., Singh, S., Dutta, D., Chaudhuri, S., Ganguly, S., \& Nain, L. (2014). Statistical optimization of media components for production of fibrinolytic alkaline metalloproteases from Xenorhabdus indica KB-3. Biotechnology Research International, 2014, 1-11. http://dx.doi. org/10.1155/2014/293434. PMid:24864214.

Prihanto, A.A., Darius, \& Firdaus, M. (2013). Proteolytic and fibrinolytic activities of halophilic lactic acid bacteria from two indonesian fermented foods. Journal of Microbiology, Biotechnology and Food Sciences, 2(5), 2291-2293.

Saitou, N., \& Nei, M. (1987). The neighbor-joining method: a new method for reconstructing phylogenetic trees. Molecular Biology and Evolution, 4(4), 406-425. PMid:3447015.

Sanger, F., \& Coulson, A. R. (1975). A rapid method for determining sequences in DNA by primed synthesis with DNA polymerase. Journal of Molecular Biology, 94(3), 441-448. http://dx.doi.org/10.1016/00222836(75)90213-2. PMid:1100841.

Seo, J. H., \& Lee, S. P. (2004). Production of fibrinolytic enzyme from soybean grits fermented by Bacillus firmus NA-1. Journal of Medicinal Food, 7(4), 442-449. http://dx.doi.org/10.1089/jmf.2004.7.442. PMid:15671687.
Simkhada, R., Mander, P., Cho, S. S., \& Yoo, J. C. (2010). A novel fibrinolytic protease from Streptomyces sp. CS684. Process Biochemistry, 45(1), 88-93. http://dx.doi.org/10.1016/j.procbio.2009.08.010.

Stephani, L., Tjandrawinata, R. R., Afifah, D. N., Lim, Y., Ismaya, W. T., \& Suhartono, M. T. (2017). Food origin fibrinolytic enzyme with multiple actions. Hayati Journal of Biosciences, 24(3), 124-130. http:// dx.doi.org/10.1016/j.hjb.2017.09.003.

Sugimoto, S., Fujii, T., Morimiya, T., Johdo, O., \& Nakamura, T. (2007). The fibrinolytic activity of a novel protease derived from tempeh producing fungus, Fusarium sp. BLB. Bioscience, Biotechnology, and Biochemistry, 71(9), 2184-2189. http://dx.doi.org/10.1271/ bbb.70153. PMid:17827689.

Sumi, H., Hamada, H., Tsushima, H., Mihara, H., \& Muraki, H. (1987). A novel fibrinolytic enzyme (nattokinase) in the vegetable cheese Natto; a typical and popular soybean food in the Japanese diet. Experientia, 43(10), 1110-1111. http://dx.doi.org/10.1007/ BF01956052. PMid:3478223.

Sumi, H., Nakajima, N., \& Yatagai, C. (1995). A unique strong fibrinolytic enzyme (datsuwokinase) in skipjack "Shiokara", a Japanese traditional fermented food. Comparative Biochemistry and Physiology, 112(3), 543-547. http://dx.doi.org/10.1016/03050491(95)00100-X. PMid:8529030.

Vijayaraghavan, P., \& Prakash Vincent, S. G. (2014). Medium optimization for the production of fibrinolytic enzyme by Paenibacillus sp. IND8 using response surface methodology. TheScientificWorldJournal, 2014, 1-9. http://dx.doi.org/10.1155/2014/276942. PMid:24523635.

Voet, D., \& Voet, J. G. (1997). Biochemistry (2nd ed.). New York: John Wiley \& Sons, Incorporated.

Wei, X., Luo, M., Xu, L., Zhang, Y., Lin, X., Kong, P., \& Liu, H. (2011). Production of fibrinolytic enzyme from Bacillus amyloliquefaciens by fermentation of chickpeas, with the evaluation of the anticoagulant and antioxidant properties of chickpeas. Journal of Agricultural and Food Chemistry, 59(8), 3957-3963. http://dx.doi.org/10.1021/ jf1049535. PMid:21391672.

World Health Organization - WHO. (2017). Cardiovascular diseases (CVDs). Geneva: WHO. Retrieved from: https://www.who.int/ cardiovascular_diseases/world-heart-day/en/

Wu, J. X., Zhao, X. Y., Pan, R., \& He, R. Q. (2007). Glycosylated trypsin-like proteases from earthworm Eisenia fetida. International Journal of Biological Macromolecules, 40(5), 399-406. http://dx.doi. org/10.1016/j.ijbiomac.2006.10.001. PMid:17113141.

Xiao-lan, L., Lian-Xiang, D., Fu-Ping, L., Xi-Qun, Z., \& Jing, X. (2005). Purification and characterization of a novel fibrinolytic enzyme from Rhizopus chinensis 12. Applied Microbiology and Biotechnology, 67(2), 209-214. http://dx.doi.org/10.1007/s00253-004-1846-5. PMid:15614557.

Yamashita, T., Oda, E., Giddings, J. C., \& Yamamoto, J. (2003). The Effect of dietary Bacillus natto productive protein on in vivo endogenous thrombolysis. Pathophysiology of Haemostasis and Thrombosis, 33(3), 138-143. http://dx.doi.org/10.1159/000077822. PMid:15170394.

Yogesh, D., \& Halami, P. M. (2015). Evidence that multiple proteases of Bacillus subtilis can degrade fibrin and fibrinogen. International Food Research Journal, 22(4), 1662-1667.

Yogesh, D., \& Halami, P. M. (2017). Fibrinolytic enzymes of Bacillus spp.: an overview. International Food Research Journal, 24(1), 35-47.

Zhu, Y., \& Tramper, J. (2013). Koji - Where east meets west in fermentation. Biotechnology Advances, 31(8), 1448-1457. http:// dx.doi.org/10.1016/j.biotechadv.2013.07.001. PMid:23850857. 